\title{
Revision of the genus Heteropsyllus (Copepoda: Harpacticoida) with description of a new species from the Laptev Sea and establishment of new genus
}

\section{Ревизия рода Heteropsyllus (Copepoda: Harpacticoida) с описанием нового вида из моря Ааптевых и выделением нового рода}

\author{
A.A. Novikov ${ }^{1}$, D.N. Sharafutdinova \\ А.А. Новиков ${ }^{1}$, А.Н. ШарафутАинова
}

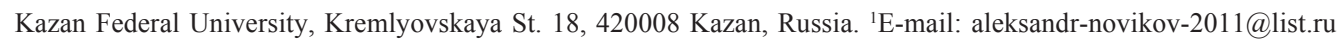
Казанский федеральный университет, ул. Кремлевская 18, Казань, 420008 Россия. ${ }^{1}$ Corresponding author.

KEY WORDS: Arctic ocean, arctic fauna, meiobenthic Copepoda, taxonomy, phylogeny.

КЛЮЧЕВЫЕ СЛОВА: Северный Ледовитый океан, арктическая фауна, мейобентосные Copepoda, таксономия, филогения.

ABSTRACT. A phylogenetic analysis of species of the genus Heteropsyllus T. Scott, 1894 was carried out on the basis of morphological characteristics. The polyphyly of the genus was shown; two species, Heteropsyllus nunni Coull, 1975 and H. pseudonunni Coull et Palmer, 1980, were transferred to the genus Coullopsyllus gen.n. in the family Nannopodidae. From other genera, Coullopsyllus gen.n. differed in the 3-segmented endopod of the first leg and 2-segmented endopod of the fourth leg. It differed from Heteropsyllus in the absence of sexual dimorphism in the third leg and in the four setae on the fifth leg of the male. A new species, H. spiridonovi sp.n. from the Laptev Sea, which belongs to the $H$. curticaudatus species group, was also described. It differed from closely related species by the following combination of characteristics: smooth surface of somites, 2-segmented exopod of antenna, free exopod of mandible, three endites on syncoxa of maxilla, and the absence of a cuticular area on the fifth pair of legs.

How to cite this paper: Novikov A.A., Sharafutdinova D.N. 2021. Revision of the genus Heteropsyllus (Copepoda: Harpacticoida) with description of a new species from the Laptev Sea and establishment of new genus // Arthropoda Selecta. Vol.30. No.3. P.405-421, Supplement. doi: 10.15298/arthsel.30.3.12

РЕЗЮМЕ. На основе морфологических признаков проведен филогенетический анализ видов рода Heteropsyllus T. Scott, 1894. Показана полифилия рода, два вида: Heteropsyllus nunni Coull, 1975 и $H$. pseudonunni Coull et Palmer, 1980 перенесены в род Coullopsyllus gen.n. в семействе Nannopodidae. От других родов Coullopsyllus gen.n. отличается 3-сегментным эндоподитом 1-й пары ног и 2-сегментным эндоподитом 4-й пары ног. От Heteropsyllus отличается отсутствием полового диморфизма 3-й пары ног и четырьмя щетинками на 5-й паре ног самца. Также описан новый вид $H$. spiridonovi sp.n. из моря Лаптевых, который входит в группу видов H. curticaudatus. От близких видов отличается следующей комбинацией признаков: гладкая поверхность сомитов, 2-сегментный экзоподит антенны, свободный экзоподит мандибулы, три эндита на синкоксе максиллы, отсутствие кутикулярной области на 5-й паре ног.

\section{Introduction}

As studies in recent years have shown, the meiobenthic harpacticoids of the Arctic seas have been studied poorly; in many of the studied samples, the number of new species is about half of all species. Undoubtedly, the majority belong to the most abundant families in these seas, such as Miraciidae Dana, 1846, Canthocamptidae Brady, 1880, Argestidae Por, 1986, and Ectinosomatidae G.O. Sars, 1903.

The genus Heteropsyllus T. Scott, 1894 can be referred to as the mass genera Canthocamptidae s. lat. This genus, which is quite complex for taxonomy, was initially attributed to Cletodidae T. Scott, 1904 [Lang, 1948] and later transferred to Canthocamptidae [Por, 1986]. Kornev \& Chertoprud [2008] separated the genus into a monotypic family Heteropsyllidae Kornev et Chertoprud, 2008. Following that, some authors still indicated this genus as part of the Canthocamptidae family [George, 2013; Garlitska et al., 2019], including the recently described species Heteropsyllus spongiophilus Novikov et Sharafutdinova, 2021. The authors indicated the similarity of Heteropsyllus in some characteristics to Hemimesochrinae; however, they do not indicate the exact position [Novikov, Sharafutdinova, 2021]. 
Revision of the material for the marine Canthocamptidae showed a significant difference between Heteropsyllus and all other genera. Therefore, this genus should be separated into the family Heteropsyllidae, according to Kornev \& Chertoprud [2008].

Representatives of the genus differ significantly among themselves both in the structure of the mouthparts and in ecology. Therefore, this study evaluated the relationship between the species of the genus and described one new species.

\section{Materials and methods}

The material was collected during the "Lena-2019" expedition near the Lena River delta in the southern part of the Laptev Sea. The material was collected using a UWITEC sampler. The top 3 centimeters of the core were washed with tap water in a small plankton net. Samples were fixed in 4\% formalin. Specimens were dissected under a stereomicroscope, with each element being placed under a separate cover slip. Rough drawings were generated on printed photographs of elements, and the final drawings were prepared using the free program Inkscape 1.0.

Cladistic analysis of the genus Heteropsyllus was performed using the PAUP 4.0a. The matrix is based on a binary principle and includes 54 characters. To construct trees, the parsimony method was used, where all features are irreversible. The list of morphological characters is given in Table 3, the matrix is in Supplement 1.

All material was deposited in Zoological museum of Kazan Federal University.

Nomenclature and descriptive terminology follows Huys \& Boxshall [1991], terminology in genital fields follows Moura \& Pottek [1998], terminology in mandibular structure follows Mielke [1984].

Abbreviations used in the text: ae - aesthetasc, acr acrothek, A1 - antennule, A2 - antenna, P1-P6 - legs 16, Exp1-Exp3 - first-third segments of exopod, Enp1Enp3 - first-third segments of endopod.

\section{Results}

Subclass Copepoda H. Milne-Edwards, 1840 Order Harpacticoida Sars, 1903

Family Heteropsyllidae Kornev et Chertoprud, 2008 Heteropsyllus Scott T., 1894 Heteropsyllus spiridonovi sp.n. Figs 1-9.

urn:1sid:zoobank.org:act:8FC9CD43-4FB5-493C-873D2D31AAD794CA

ETYMOLOGY. This species is named in honour of V.A. Spiridonov of the P.P. Shirshov Institute of Oceanology Russian Academy of Science, who was a well-known Russian carcinologist.

TYPE LOCALITY. Laptev Sea, southern part, east of the Lena River delta $\left(72.554472^{\circ} \mathrm{N}, 131.315722^{\circ} \mathrm{E}\right)$, depth 19 m, salinity 29.7\%o, leg. Waldemar Schneider, 7.08.2019.

MATERIAL EXAMINED. Holotype, female, dissected and mounted on 2 slides (BP 545/1-a; 545/1-b). Allotype, male dissected and mounted on one slide $(545 / 2)$.

DESCRIPTION. Female. Female. Body cylindrical (Fig. 1A). Total body length from anterior margin of rostrum to posterior margin of caudal rami: $0.417 \mathrm{~mm}$. Naupliar eye not discernible. Cephalothorax (Fig. 1B, C) consisting of cephalosome with fused first pedigerous somite, wider as remaining somites, largest width $0.102 \mathrm{~mm}$. Rostrum clearly separate from the cephalothorax, with one pair of sensilla and one unpaired pore. Posterior margin of cephalothorax and fourth-fifth pedigerous somites smooth; posterior margin of second-third pedigerous somites with hyaline frills with long "hairs".

Cephalothorax with 24 pairs of sensilla, one unpaired sensilla and 6 pairs of pores. Second pedigerous somite with 6 pairs of sensilla, one unpaired pore and one pair of lateral pores. Third pedigerous somite with 6 pairs of sensilla, one pair of lateral pores and one dorsal unpaired pore. Fourth pedigerous somite with 6 pairs of sensilla and one pair of pores. Fifth pedigerous somite with 3 pairs of sensilla and one pair of pores.

Abdomen (Fig. 2A-C) consisting of genital-double somite, two free abdominal somites and anal somite with caudal rami. All somites except anal somite on posterior margin with hyaline frills with long "hairs", on surface with poorly ordered small spinules. Genital-double somite wider than long; with dorso-lateral rows of small spinules, on posterior margin with lateral and ventral large and dorsolateral small rows of spinules; with 8 pairs of sensilla, one pair of lateral pores and one pair of ventral large pores. P6 (Fig. 2C) fused with somite with 2 naked setae. Genital field (Fig. 2C) compact, laterally with sieve; copulatory pore in middle of somite, copulatory duct strongly chitinised wide and short, extending proximally to pair of labyrinthic rounded ducts.

First free abdominal somite with four pairs of sensilla, one pair of lateral pores; on posterior margin with ventrolateral row of large spinules and dorsal row of small spinules. Second free abdominal somite with pair of dorso-lateral pores and on posterior margin with ventro-lateral row of spinules. Anal somite with one pair of sensilla, two pairs of lateral pores, one pair of ventral pores and rows of spinules. Anal operculum wide, serrated.

Caudal rami (Fig. 2A-C). Length/width ratio 1.6, with one dorsal and two ventral pores; with rows of spinules on interior, ventro-posterior margin and two spinules at base of setae II and III. Seta I small, located between setae II and III. Apical setae IV and V broken. Seta VII triarticulated.

Antennule (Fig. 3A, B): short, 5-segmented. Segment 1 square, with one unipinnate seta, with two rows of spinules proximally and two rows of spinules at base of seta. Segment 2 with seven pinnate and two naked setae. Segment 3 with five free pinnate, one free naked setae and fused basally pinnate seta and aesthetasc. Distal segment with three "pineapple-setae" (sensu Hamond, 1971), eight naked setae and acrothek consisting of small aesthetasc and two setae fused basally. Armature formula: $1-[1], 2-[9], 3-[6+(1+\mathrm{ae})], 4-$ [1],5-[10+acr].

Antenna (Fig. 3C) with allobasis. Coxa with one spinular row. Allobasis with proximal naked and distal pinnate setae. Free endopodal segment with two lateral rows of long spinules, with two spinulose spines; distally with two rows of spinules; apically with three geniculate setae, two long spines and one small seta; outermost geniculate seta fused basally to small seta. Exopod 2-segmented; first segment with one unipinnate seta; second segment with three bipinnate setae.

Mandible (Fig. 3D). Coxa with spinules proximally. Gnathobase with few multicuspidate teeth and spinulose seta; 

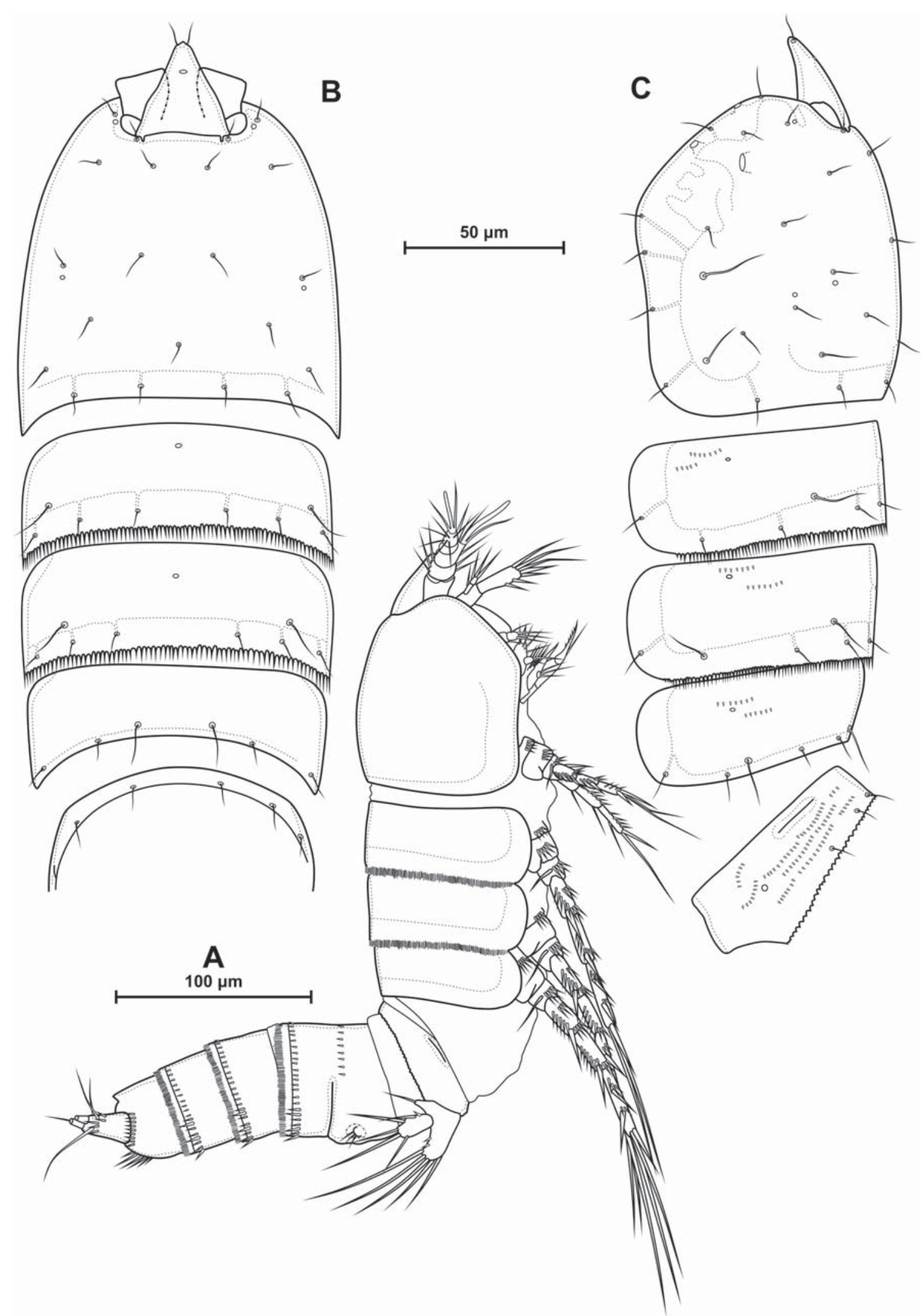

Fig. 1. Heteropsyllus spiridonovi sp.n., female holotype: A — habitus, lateral; B — cephalothorax and thoracic somites, dorsal; C cephalothorax and thoracic somites, lateral.

Рис. 1. Heteropsyllus spiridonovi sp.n., самка, голотип: А - габитус, латерально; В - цефалоторакс и торакальные сомиты, дорсально; С - цефалоторакс и торакальные сомиты, латерально. 


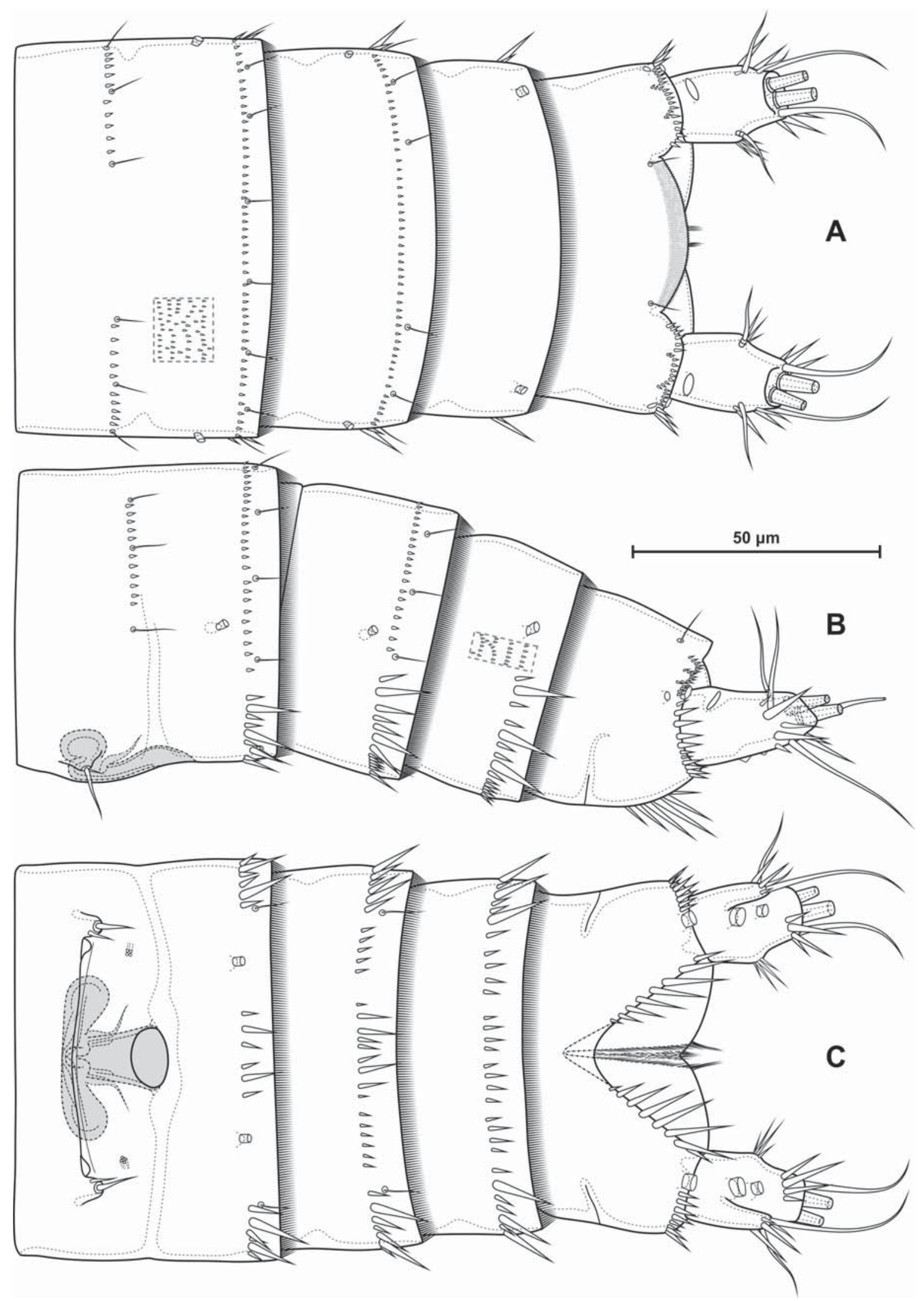

Fig. 2. Heteropsyllus spiridonovi sp.n., female holotype, abdomen: A — dorsal; B — lateral; $\mathrm{C}$ - ventral.

Рис. 2. Heteropsyllus spiridonovi sp.n., самка, голотип, абдомен: А - дорсально; В - латерально; С - вентрально. 


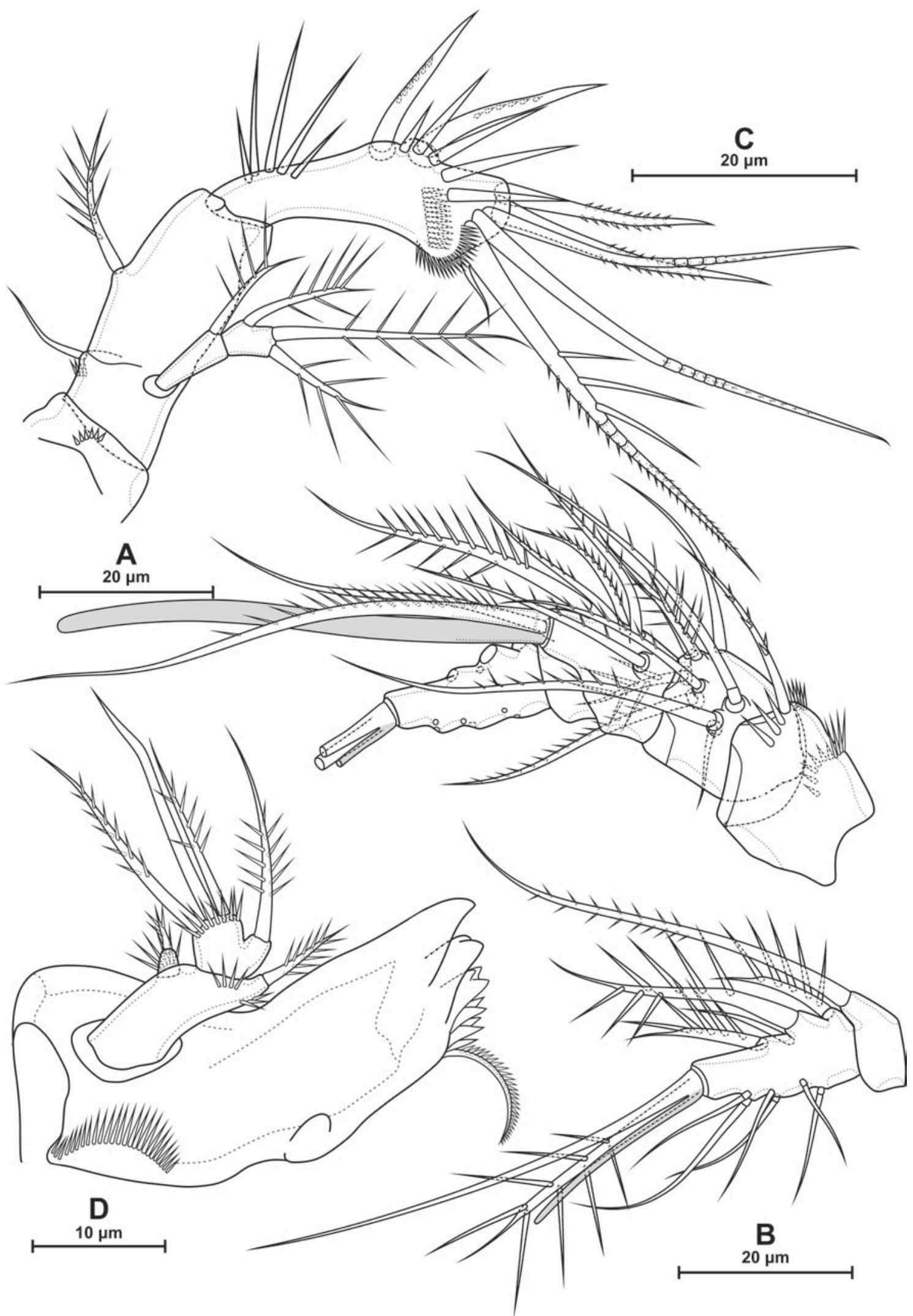

Fig. 3. Heteropsyllus spiridonovi sp.n., female holotype: A — antennule, partially; B — antennule, $4-5$ segments; C — antenna; D mandible.

Pис. 3. Heteropsyllus spiridonovi sp.n, самка, голотип: А — антеннула, частично; В — антеннула, 4-5-й сегменты; С антенна; D - мандибула. 
pars incisiva with one long tooth; lacinia mobilis with two blunt teeth. Pars molaris with sharply-edged. Palp consisting of free basis, 1-segmented endopod and exopod. Basis with two rows of spinules and one inner pinnate seta; exopod with row of spinules and one pinnate short seta; Endopod with one spinular row, one pinnate proximal seta, two distal pinnate setae and one distal naked seta.

Maxillule (Fig. 4A). Praecoxa with one row of slender spinules on outer edge. Praecoxal arthrite medially with row of spinules and one naked seta; distally with five strong spines, one small spine and two proximal setae. Coxa with row of large spinules, coxal endite not reaching middle of arthrite, with one geniculate seta. Basis with two groups of spinules, two pinnate setae proximally and one pinnate seta, one naked seta and geniculate setae distally. Endopod incorporated into basis, represented by protuberance with one pinnate setae. Exopod free, with spinular row, one small seta and one pinnate seta.

Maxilla (Fig. 4B). Syncoxa with several rows of spinules on outer and inner edge as figured, with three endites. Proximal endite with one strong bipinnate seta, middle and distal endites with three pinnate setae. Allobasis with one seta, one tube pore and massive distal claw. Endopod reduced with three naked setae.

Maxilliped (Fig. 4C) subchelate. Syncoxa elongated with several rows of spinules as figured, distally with one small bipinnate seta. Basis with one row of large inner spinules and two rows of outer slender spinules. Endopod on posterior side with one seta, on anterior side with one small seta. Endopodal claw elongated, with three small spinules.

P1 (Fig. 5A) with 3-segmented rami. Armature formula $\mathrm{P} 1-\mathrm{P} 4$ in Table 1. Praecoxa with row of spinules. Coxa wide, with three spinular row. Intercoxal sclerite expanded. Basis with proximal pore, medial row of spinules, rows of spinules at base of endopod and exopod, row of spinules at base of inner seta, with outer naked seta and inner strong pinnate seta. All endopodal and exopodal segments with outer spinules. First and second exopodal segments with one outer spine; third exopodal segment with two outer spines and two apical long geniculate setae. Endopod slightly longer than exopod. First and second endopodal segments with one seta, third segment with outer spine, apical long geniculate seta and inner pinnate seta.

P2 (Fig. 6A). Praecoxa with row of spinules. Coxa with inner fold, with one lateral row of spinules and three closely spaced proximal rows of spinules. Basis with proximal pore, medial row of spinules, two rows of slender spinules on inner edge, rows of spinules at base of endopod and exopod; with outer seta. All endopodal and exopodal segments with outer spinules. Exopod 3-segmented; first exopodal segment with outer spine, inner row of slender spinules and apically with frill; second segment with outer spine, inner seta, inner spinules and apical frill; third segment with three outer spines, two apical setae and one inner seta. Endopod 2segmented; first segment with inner seta and pore, second segment with outer spine, two apical setae, one of which short and naked, and two inner setae.

P3 (Fig. 6B) similar to P2. Praecoxa, intercoxal sclerite and coxa as in P2. Basis with only one inner row of slender spinules. Exopod as in P2, but third exopodal segment P3 with two inner setae. Endopod also as in P2, but first segment without pore and second segment with proximal pore.

P4 (Fig. 6C) also similar to P2. Praecoxa, intercoxal sclerite and coxa as in P2. Basis without medial row of spinules and with only one row of inner spinules. Exopod as in P2, but third exopodal segment P4 with two inner setae, distal of which with strong spinules. Endopod small with row of spinules on posterior side; first segment with inner seta; second segment with bipinnate and naked setae apically and two pinnate setae on inner side.

P5 (Fig. 5B) with separate right and left baseoendopods. Baseoendopod reaching about end of exopodal segment; with spinular rows on inner and outer side of endopodal lobe and at base of outer seta; outer seta of basis naked. Endopodal lobe with two pores, three outer bipinnate setae and two inner pectinate setae. Exopod small, length/width ratio 1.67; with long spinules on inner and anterior side; with five setae.

Male. Sexual dimorphism expressed in the antennule, P3, P5, P6, genital segmentation and ornamentation. Abdomen (Fig. 7A-C) narrower than female. Ornamentation and sensilla of somites 1, 2, 4 and 5 as in female, but spinules larger. Somite 3 also as in female, but with one pair of ventral pores. P6 fused with first abdominal somite, with two bare setae. Anal operculum and caudal rami as in female. Spermatophore (Fig. 9A) as figured.

Antennule (Fig. 8A-E) 9-segmented, haplocer with geniculation between segments 7 and 8. "Pineapple-setae" located on 5-7 segments. Segment 1 with four rows of spinules. Segment 5 with large aestetasc fused at base with long unipinnate seta. Segment 7 with group of slender spinules, with two modified lamellar setae, one "pineapple-seta" and one naked seta. Segment 8 with two modified lamellar setae and one simple distal seta. Segment 9 with acrothek consisting of small aestetasc and two setae. Armature formula: 1$[1], 2-[11], 3-[8], 4-[2], 5-[6+(1+\mathrm{ae})], 6-[2], 7-[2+2$ modified], $8-[1+2$ modified], $9-[8+$ acr $]$.

$\mathrm{P} 2$ and $\mathrm{P} 4$ as in female. Slight differences in spinules size and proportion of segments.

P3 (Fig. 9B-D). Praecoxa, coxa, basis, first endopodal segment and exopod as in female. Distal endopodal segment modified; outer seta curve and wide, transformed into apophysis and shifted on front side. Base of apophysis within segment. Outer apical seta naked. Inner apical seta long, bipinnate.

P5 (Fig. 9E) with left and right baseoendopods fused medially; baseoendopod with two tube pores, with one outer naked seta and three endopodal pinnate setae. Exopod short (length/width ratio 1.34), with two apical naked setae, two outer unipinnate setae.

REMARKS. The new species belongs to the H. curticaudatus species group. Despite the huge geographic range from the Mediterranean Sea through the Arctic Ocean to the Pacific to the coast of South Korea, morphological differences within this group of species are minimal, which greatly complicates the task of identification. Many differences were related to the characteristics in the structure of the mouthparts. The species of the group differ among themselves according to some characteristics presented in Table 2.

Notably, many species of this group were previously identified as $H$. major based on the armature formula of swimming legs. However, as the research of Nam \& Lee [2006] and our work showed, it is impossible to determine the species only by the key, and it is imperative to look at the original description. It is likely that, for example, some findings of H. major in the Laptev Sea and the Kara Sea [Chertoprud et al., 2018; Garlitska et al., 2019] are $H$. spiridonovi sp.n. or some other species.

Additionally, Bodin [1970] indicated H. major of the Bay of Biscay with a small description and figures of a male. A rather specific feature of the male was a cuticular area on 


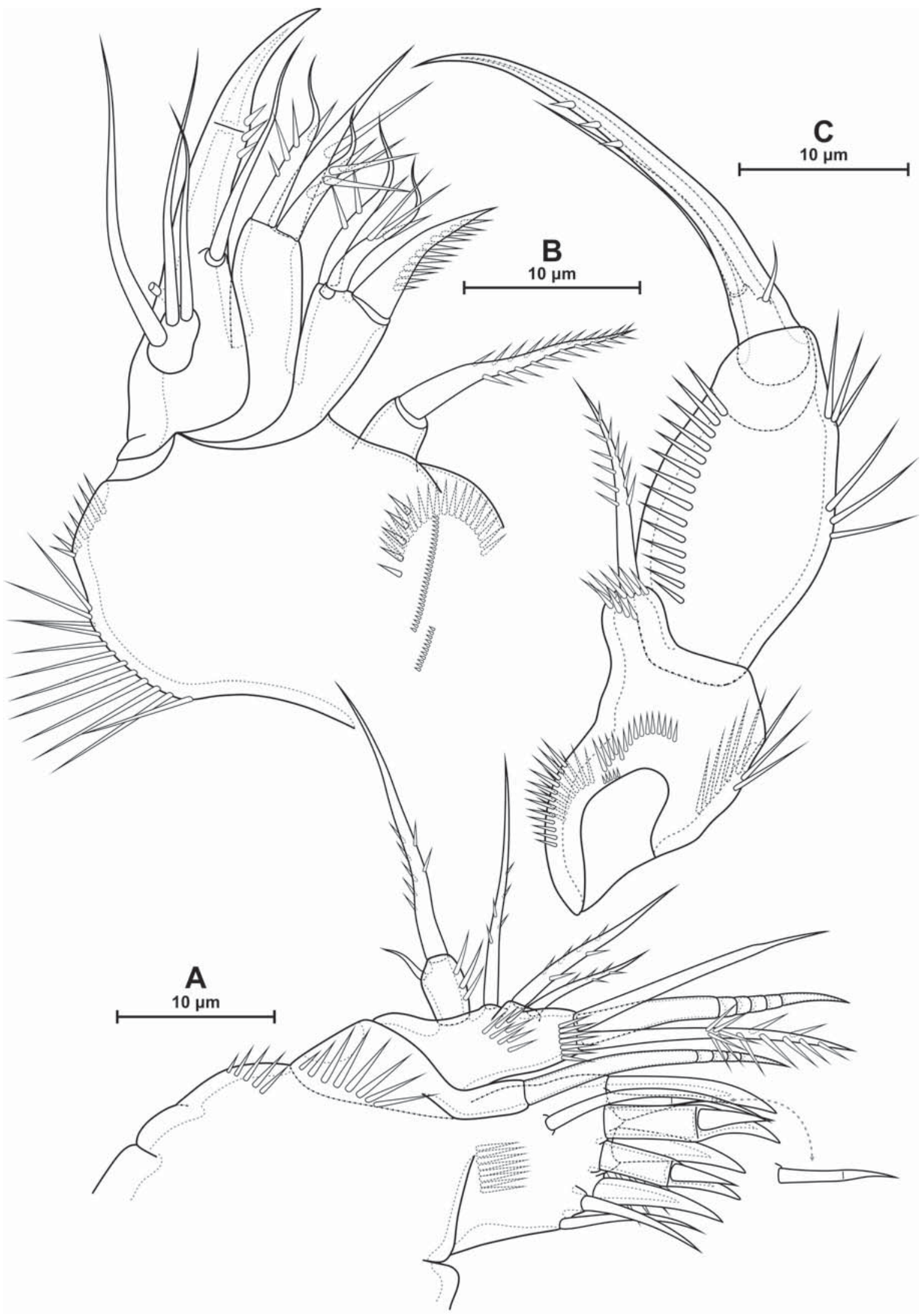

Fig. 4. Heteropsyllus spiridonovi sp.n., female holotype: $\mathrm{A}$ - maxillule; $\mathrm{B}-$ maxilla; $\mathrm{C}$ - maxilliped.

Pис. 4. Heteropsyllus spiridonovi sp.n., самка, голотип: А — максиллула; В — максилла; С — максиллипеда. 


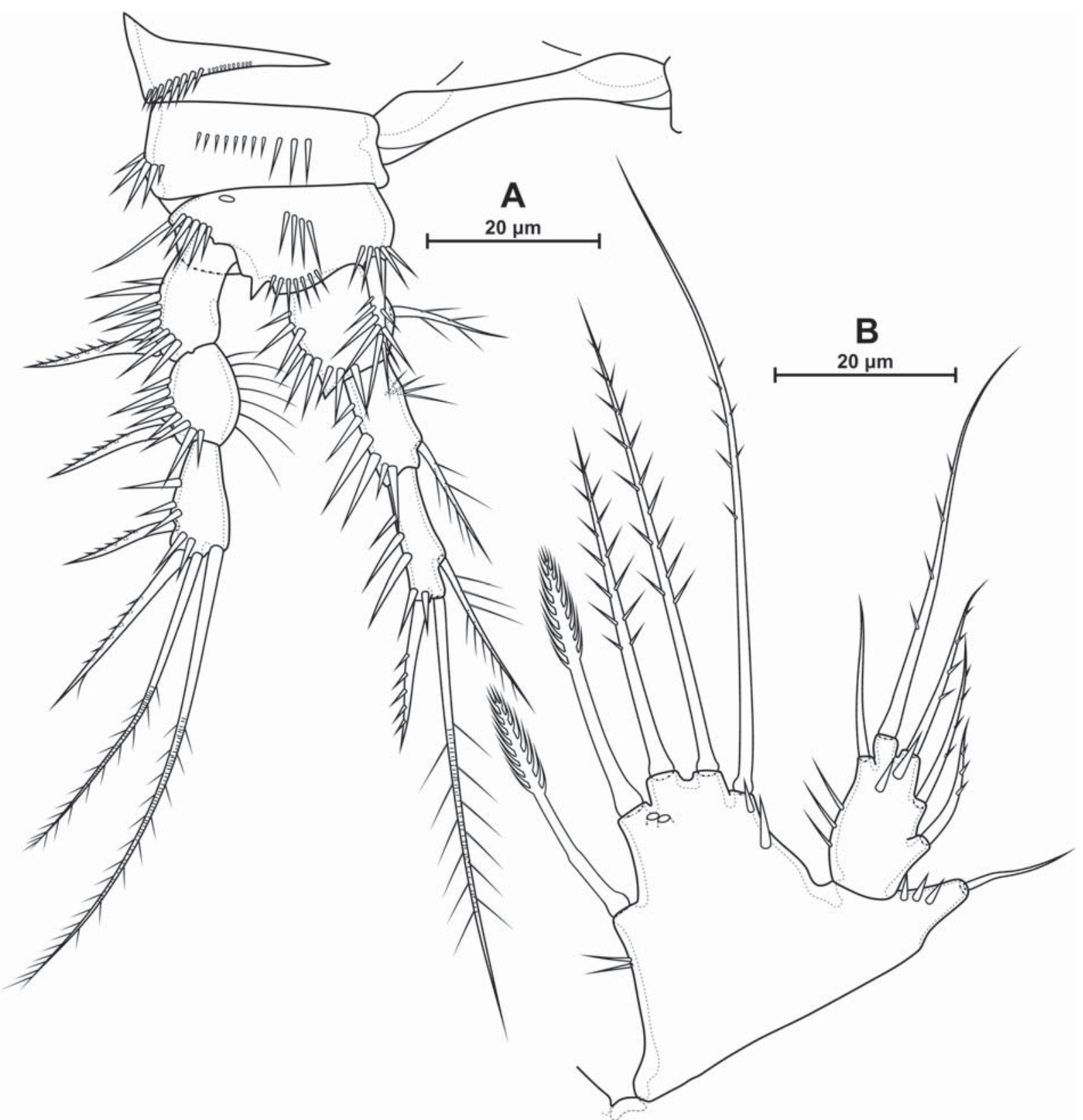

Fig. 5. Heteropsyllus spiridonovi sp.n., female holotype: A - P1, anterior; B $-\mathrm{P} 5$, anterior. Рис. 5. Heteropsyllus spiridonovi sp.n., самка, голотип: А - Р1, спереди; В - Р5, спереди.

Table 1. Armature formula of female P1-P4 of $H$. spiridonovi sp.n. Таблица 1. Формула вооружения Р1-P4 самки H. spiridonovi sp.n

\begin{tabular}{lll}
\hline & endopod & exopod \\
\hline P1 & $1 ; 1 ; 1,1,1$ & $0 ; 0 ; 0,2,2$ \\
P2 & $1 ; 2,2,1$ & $0 ; 1 ; 1,2,3$ \\
P3 & $1 ; 2,2,1$ & $0 ; 1 ; 2,2,3$ \\
P4 & $1 ; 2,2,0$ & $0 ; 1 ; 2,2,3$ \\
\hline
\end{tabular}

P5, which was not present in Sars's figures [1920]. Bodin also wrote that Sars probably made a mistake by drawing a mandible without an exopod. However, it is very unlikely that Sars could have made a mistake in the description. Therefore, it is likely that Bodin was dealing with another undescribed species from this group.

PHYLOGENY. As a result of cladistic analysis based on morphological features, we obtained 40 trees with the same values of length, consistency index (CI) and a retention index (RI) (103, 0.524, 0.793, respectively). Figure 10 shows a consensus tree based on these trees using the Majorityrule, taxa with less than $50 \%$ support are not displayed.

Based on this tree, significant differences were observed between the two American species, H. nunni and H. pseudonunni, from the rest of the other species. Moreover, a careful comparison of various characteristics generally speaks of 


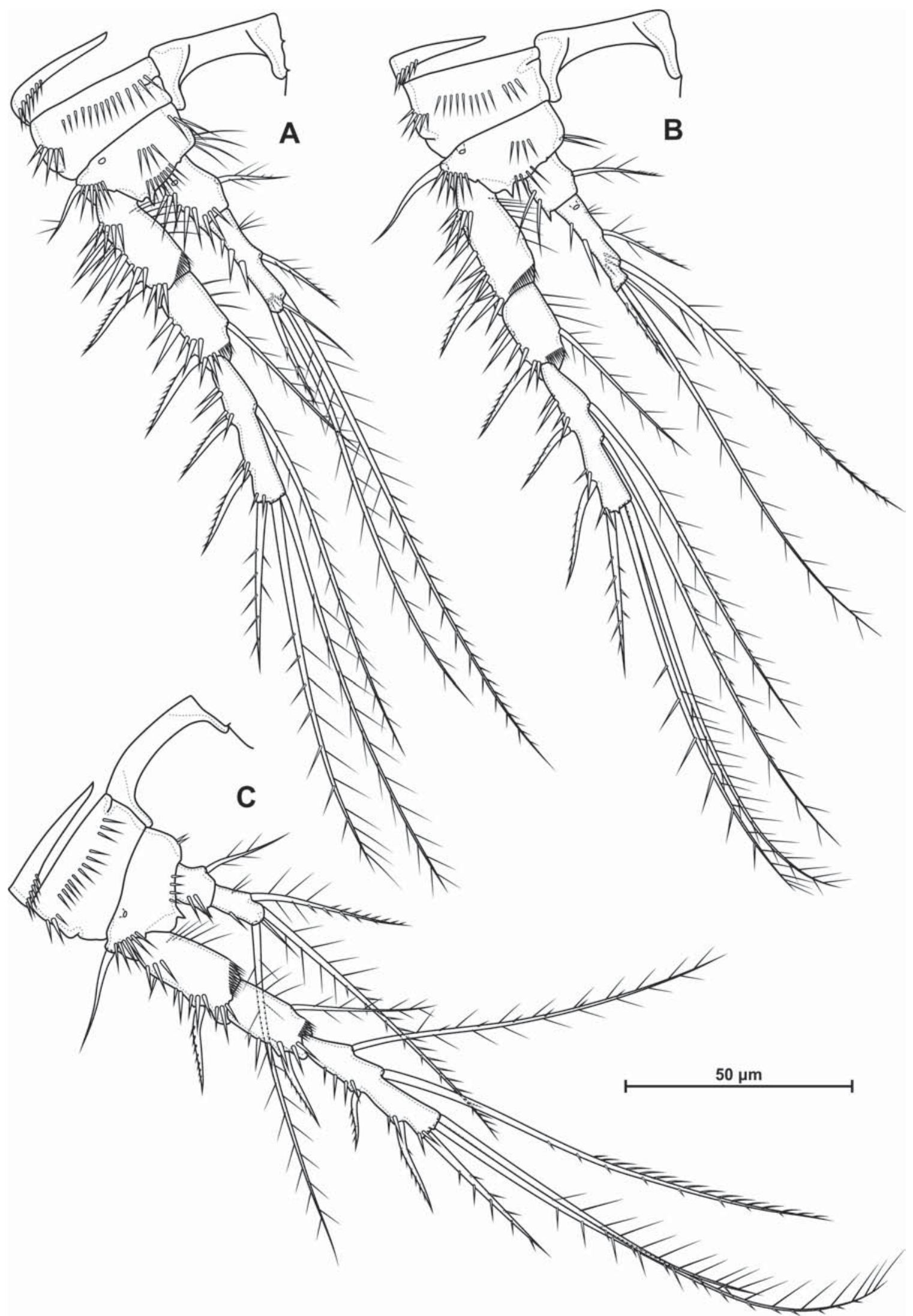

Fig. 6. Heteropsyllus spiridonovi sp.n., female holotype: $\mathrm{A}-\mathrm{P} 2$, anterior; $\mathrm{B}-\mathrm{P} 3$, anterior; $\mathrm{C}-\mathrm{P} 4$, anterior. Рис. 6. Heteropsyllus spiridonovi sp.n., самка, голотип: А - Р2, спереди; В - Р3, спереди; С - Р4, спереди. 


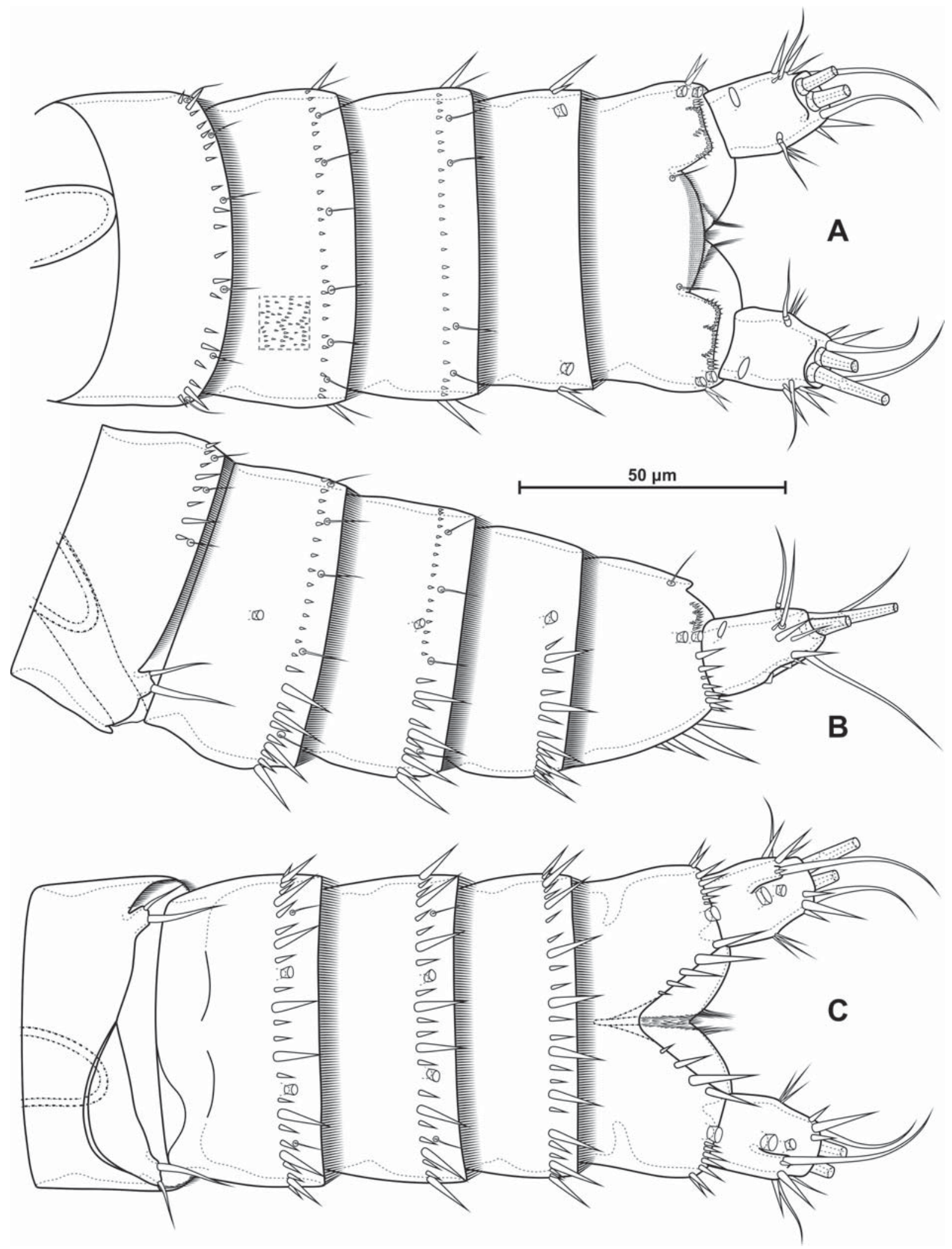

Fig. 7. Heteropsyllus spiridonovi sp.n., male allotype, abdomen: A — dorsal; B - lateral; C — ventral.

Pис. 7. Heteropsyllus spiridonovi sp.n., самец, аллотип, абдомен: А — дорсально; В - латерально; С - вентрально. 


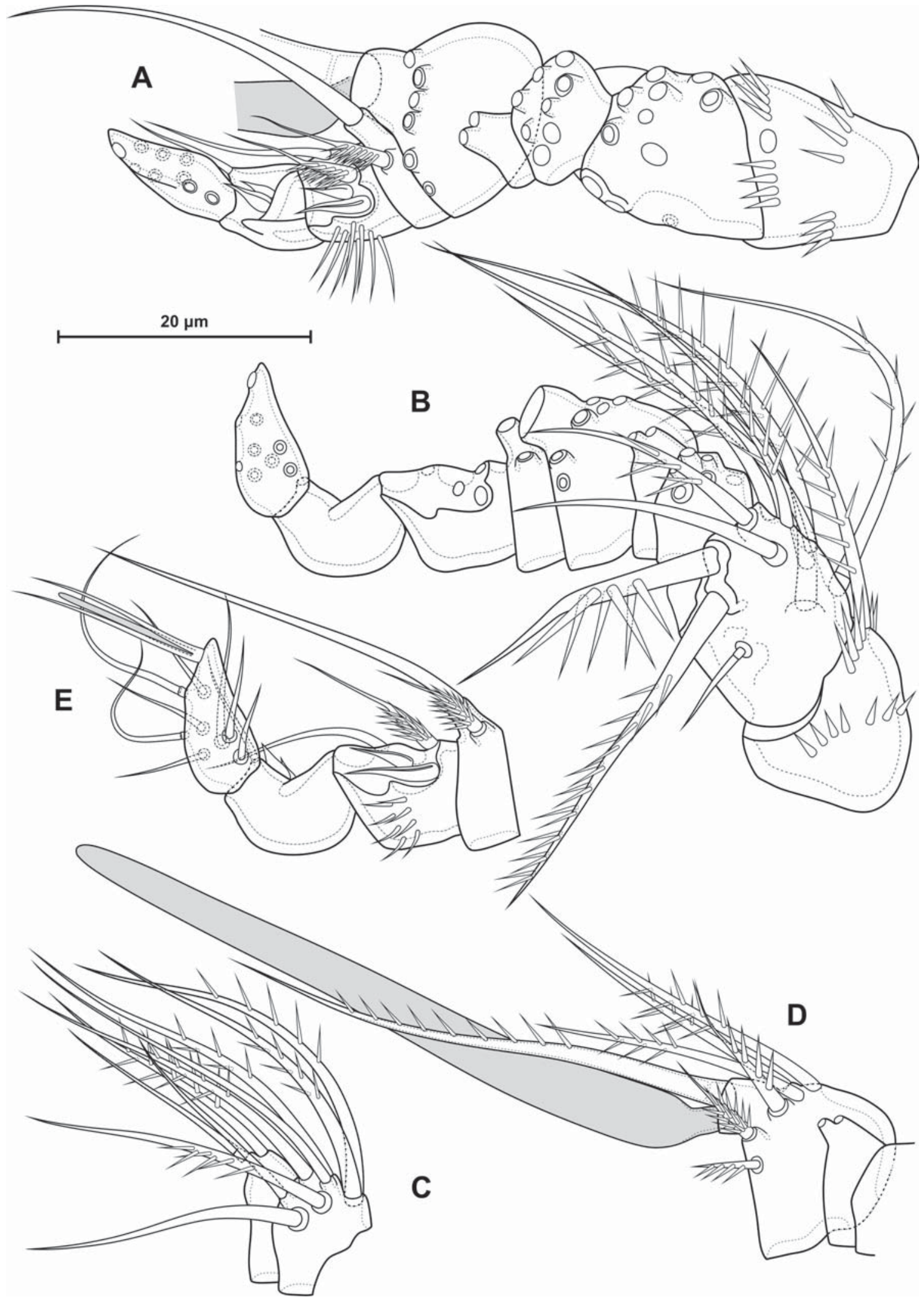

Fig. 8. Heteropsyllus spiridonovi sp.n., male allotype, antennule: A — anterior; B — dorsal, partially; C - 3-4 segments, dorsal; D 5 segment, dorsal; $\mathrm{C}-6-9$ segments, dorsal.

Рис. 8. Heteropsyllus spiridonovi sp.n., самец, аллотип, антеннула: А - спереди; В - сверху, частично; С - 3-4-й сегменты, сверху; D - 5-й сегмент, сверху; С - 6-9-й сегменты, сверху. 


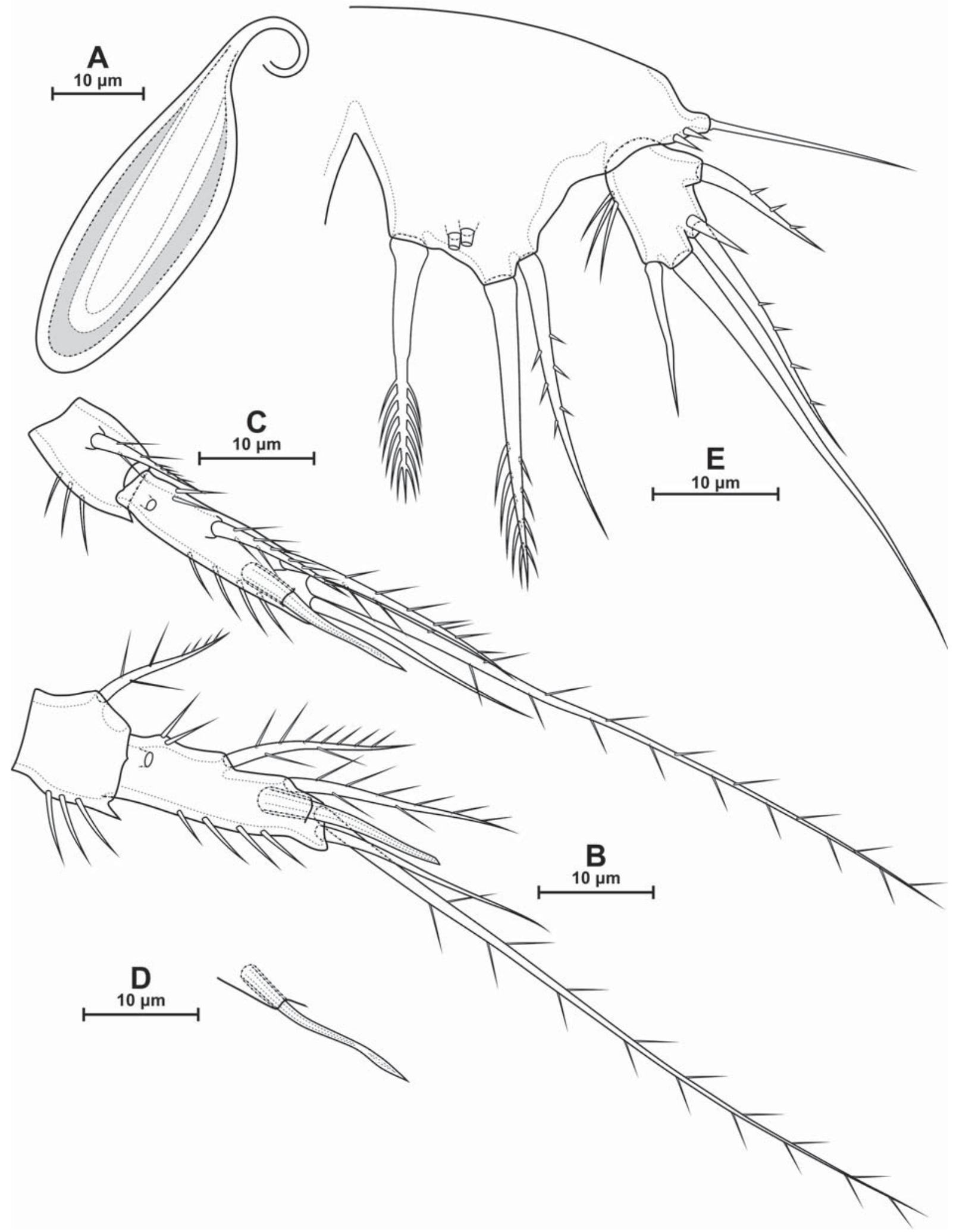

Fig. 9. Heteropsyllus spiridonovi sp.n., male allotype: A - spermatophore; B - P3 endopod, anterior; C - P3 endopod, frontalinternal view; D - P3 endopod, apophysis, internal view; E - P5, anterior.

Рис. 9. Heteropsyllus spiridonovi sp.n., самец, аллотип, антеннула: А - сперматофор; В - Р3 эндоподит, спереди; С - Р3 эндоподит, передне-внутренний вид; D - Р3 эндоподит, апофиза, внутренний вид; Е — Р5, спереди. 
Table 2. Differences between species in H. curticaudatus species group. Таблица 2. Различия между видами в группе видов H. curticaudatus.

\begin{tabular}{|c|c|c|c|c|c|c|c|}
\hline character & H. celticus & $\begin{array}{c}H . \\
\text { coreanus }\end{array}$ & $\begin{array}{c}H . \\
\text { spiridonovi } \\
\text { sp.n. }\end{array}$ & $\begin{array}{l}\text { H. major } \\
\text { sensu Lang }\end{array}$ & $\begin{array}{c}\text { H. major } \\
\text { sensu } \\
\text { Bodin }\end{array}$ & H. nanus & $\begin{array}{c}H . \\
\text { curticaudatus }\end{array}$ \\
\hline $\begin{array}{l}\text { Surface of } \\
\text { somites }\end{array}$ & areolated & areolated & normal & normal & normal & normal & normal \\
\hline A2 exopod & 2-segmented & $\begin{array}{c}1- \\
\text { segmented }\end{array}$ & $\begin{array}{c}2- \\
\text { segmented }\end{array}$ & $\begin{array}{c}2- \\
\text { segmented }\end{array}$ & $\begin{array}{c}2- \\
\text { segmented }\end{array}$ & $\begin{array}{c}2- \\
\text { segmented }\end{array}$ & 2-segmented \\
\hline $\begin{array}{l}\text { Mandible exopod } \\
\text { with one seta }\end{array}$ & present & present & present & absent & present & present & present \\
\hline $\begin{array}{l}\text { Maxillule, coxal } \\
\text { endite, setae }\end{array}$ & 1 & 1 & 1 & 2 & 2 & 2 & $?$ \\
\hline $\begin{array}{l}\text { Maxilla, proximal } \\
\text { endite }\end{array}$ & present & present & present & absent & absent & absent & $?$ \\
\hline $\begin{array}{l}\text { P4 Enp2, inner } \\
\text { setae }\end{array}$ & 2 & 2 & 2 & 2 & 2 & 2 & 1 \\
\hline $\begin{array}{l}\text { P5, circular } \\
\text { wrinkled area }\end{array}$ & present & present & absent & absent & present & absent & present \\
\hline $\begin{array}{l}\text { Male P5, exopod, } \\
\text { inner seta }\end{array}$ & absent & absent & absent & absent & present & $?$ & $?$ \\
\hline
\end{tabular}

belonging not only to another genus but to another family. There are a number of features generally uncharacteristic of the genus, including a fused exopod and basis of maxillule, absence of proximal endite of maxilla, presence of internal setae on Exp2 P1, only three setae on Enp2 P2, absence of sexual dimorphism in the structure of Enp2 P3, absence of setae on Enp1 P4, four setae on baseoendopod, and six setae on exopod P5 of male.

In many ways, these species are similar to the family Nannopodidae Brady, 1880; it is the only member of the family Cletodidimorpha Lang, 1948 sensu Kornev et Chertoprud, 2008, whose males have four setae on P5. Obviously, the fourth seta should be regarded as an apomorphy, and not a plesiomorphy, as a kind of rollback to the state of the characteristic in the female. A similar situation was observed in sexual dimorphism in the structure of P3. In Nannopodidae, it was weakly expressed; if the outer spine of the endopodite was modified, it only fused at the base with the segment of the endopodite. Given the absence of figures of this limb for $H$. nunni and $H$. pseudonunni, it is likely that there was such a modification of the outer spine.

Another feature that brings $H$. nunni and H. pseudonun$n i$, and specifically the genus Nannopus Brady, 1880 together, is the highly modified large seta in the ventro-distal part of the maxillary arthrite. The synapomorphies of Nannopodidae and these two species also include the features of reduction in the structure of the mouthparts and swimming legs, such as the fused exopod and the basis of the maxillule, the absence of the proximal endite of the maxilla, and the absence of the inner seta of Enp1 P4. Therefore, based on these characteristics, H. nunni and H. peudonunni were transferred to Coullopsyllus gen.n. in the family Nannopodidae.
After these rearrangements, the most basal species of Heteropsyllus are two closely related Arctic species $H$. coul$l i$ and $H$. spongiophilus, which have the most primitive set of characters for the genus.

Some species are grouped doubtfully. H. serratus, which is referred to in the literature as incertae sedis, is unclear for what reason it would have been transferred to another subfamily. Comparison of Shriver's figures [1983] with other Heteropsyllus species does not show any significant differences, so we reconstruct $H$. serratus as a valid species in the genus Heteropsyllus.

One of the most well-defined clades is $H$. curticaudatus species group. It includes the following species: H. celticus, H. coreanus, H. spiridonovi sp.n., H. major, H. nanus and $H$. curticaudatus. Synapomorphies of this group of species include: three "pineapple-setae" on the last segment of female antennule, general reduction of the armature of maxillule, four setae on Enp3 P1, absence of outer spine on Enp2 P4, only two setae on male P6.

Subclass Copepoda H. Milne-Edwards, 1840 Order Harpacticoida Sars, 1903

Family Nannopodidae Brady, 1880 Genus Coullopsyllus gen.n.

urn:1sid:zoobank.org:act:290D0C7B-0163-4CE5-8DF3BA96BFE21AE1

TYPE SPECIES. Coullopsyllus nunni (Coull, 1975) comb.n.

OTHER SPECIES. Coullopsyllus pseudonunni (Coull et Palmer, 1980) comb.n. 


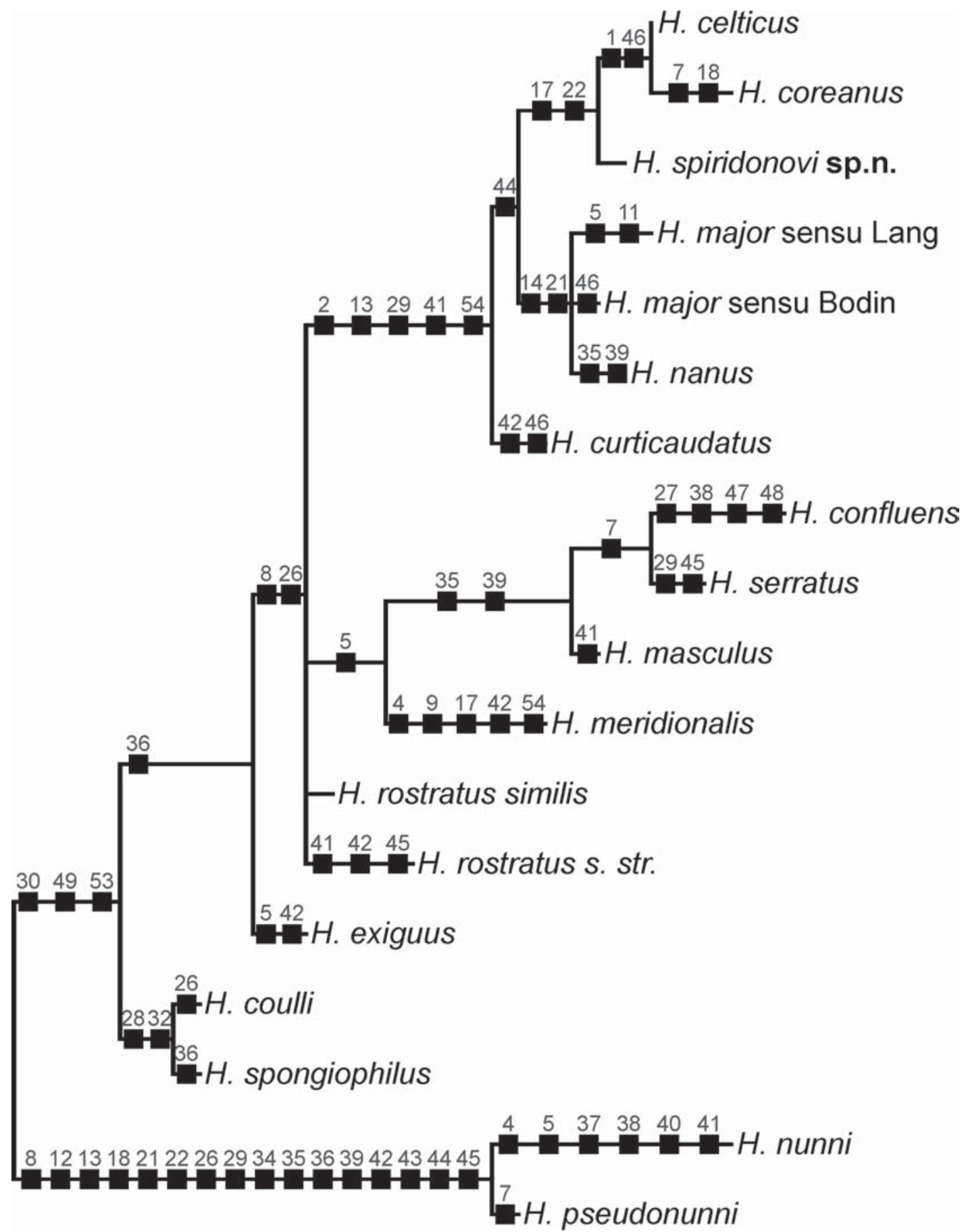

Fig. 10. Cladogram of the genus Heteropsyllus, constructed by the parsimony method based on the matrix from Supplement 1. Above the branches, black squares mark the apomorphies of characters from Table 3.

Рис. 10. Кладограмма рода Heteropsyllus, построенная методом парсимонии на основе матрицы из Приложения 1. Над ветвями черными квадратами отмечены апоморфии признаков из Табл. 3.

ETYMOLOGY. The genus is named after Dr. Bruce Coull, who described both species of this new genus.

DIAGNOSIS. Nannopodidae. Body broadened. Rostrum separated. Caudal rami short. Female antennule 5-segmented. Male antennule haplocer. Antenna with allobasis, exopod 1- to 2-segmented, with four setae. Mandible with welldevelopment gnathobase, endopod and exopod; basis with one seta. Maxillule with fused basis and exopod, praecoxal arthrite with ventro-distal strong spinulose seta. Maxilla with two syncoxal endites; endopod 1-segmented. P1 with 3 -segmented rami; first endopodal segment short, reaching about midlength of second exopodal segment. P2-P4 exopod 3-segmented, endopod 2-segmented. Armature formula P1-P4 in Table 4. 
Table 3. Morphological characters used in phylogenetic analysis. Apomorphies in parentheses.

Таблица 3. Морфологические признаки, использованные в филогенетическом анализе. Апоморфии в круглых скобках.

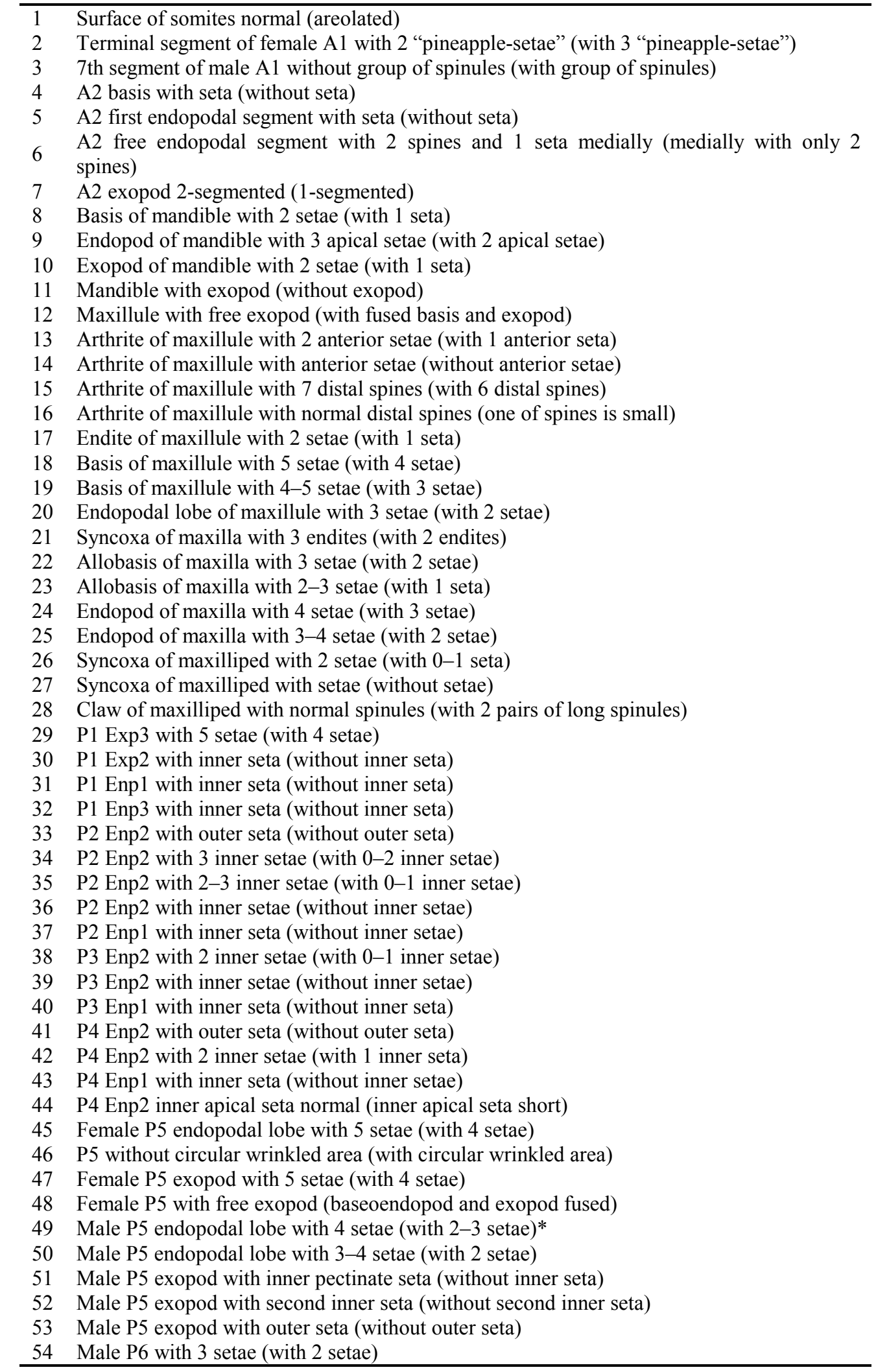


Table 4. Armature formula of females P1-P4 of Coullopsyllus gen.n.

Таблица 4. Формула вооружения P1-P4 самок Coullopsyllus gen.n.

\begin{tabular}{lll}
\hline & endopod & exopod \\
\hline P1 & $0-1 ; 1 ; 1,1,1$ & $0 ; 1 ; 0,2,2$ \\
P2 & $0-1 ; 0,2,1$ & $0 ; 1 ; 1,2,3$ \\
P3 & $0-1 ; 0-1,2,1$ & $0 ; 1 ; 2,2,3$ \\
P4 & $0 ; 0-1,2,1$ & $0 ; 1 ; 2,2,3$ \\
\hline
\end{tabular}

Female P5 with separated exopod and baseoendopod; endopodal lobe with four setae, exopod short, with 5 setae. Male P2-P4 unmodified, as in female. P5 endopodal lobr with 4 setae, outer; exopod with 6 setae.

REMARKS. As already shown, Coullopsyllus gen.n. differs well from species of the genus Heteropsyllus. In the family Nannopodidae, the new genus is likely to converge with the genus Nannopus on the basis of the similarity in the structure of the mouthparts and P5 armament. Coullopsyllus differs from all genera of the family in a number of primitive features: a 3-segment P1 endopod and a 2-segment P4 endopod.

ECOLOGY AND DISTRIBUTION. C. nunni comb.n. and $C$. pseudonunni comb.n. were found on the east coast of North America. Both species are most likely found only in brackish and fresh waters. They are an example of the invasion of brackish-water species into freshwater bodies; they were found in great lakes [Horvath et al., 2001]. The ecology of these species has been studied quite well. It is known that $C$. pseudonunni comb.n. preferentially feeds on detritus and bacteria [Ustach, 1982]. It is known that C. nunni comb.n. it is the only marine Harpacticoida with encystment diapause [Coull, Grant, 1981].

Family Heteropsyllidae Kornev et Chertoprud, 2008

DIAGNOSIS. Family diagnosis corresponds to the diagnosis of the genus Heteropsyllus.

\section{Genus Heteropsyllus T. Scott, 1894} 1894.

TYPE SPECIES. Heteropsyllus curticaudatus T. Scott,

OTHER SPECIES AND SUBSPECIES. Heteropsyllus celticus Nam et Lee, 2006; H. confluens Soyer, 1974; H. coreanus Nam et Lee, 2006; H. coulli Kornev et Chertoprud, 2008; H. exiguus (G.O. Sars, 1911); H. major (G.O. Sars, 1920); H. masculus Kunz, 1974; H. meridionalis Soyer, 1974; H. nanus (G.O. Sars, 1920); H. rostratus similis Smirnov, 1946; H. rostratus rostratus (G.O. Sars, 1920); H. serratus Schriever, 1983; H. spongiophilus Novikov et Sharafutdinova, 2021; H. spiridonovi sp.n.

AMENDED DIAGNOSIS. Heteropsyllidae. Body semicylindrical, broadened. Rostrum separated. Caudal rami short. Female antennule 5-segmented; male antennule 9-segmented, haplocer with geniculation between segments 7 and 8 . Antenna with allobasis, exopod 1-2-segmented, with four setae. Mandible with well-development gnathobase and endopod; exopod present or absent, with one seta. Maxillule with free exopod. Maxilla with three syncoxal endites; endopod 1-segmented. P1 with 3-segmented rami; first endopodal segment short, reaching about midlength of second
Table 5. Armature formula of females P1-P4 of Heteropsyllus T. Scott, 1894.

Таблица 5. Формула вооружения P1-P4 самок Heteropsyllus T. Scott, 1894.

\begin{tabular}{lll}
\hline & endopod & exopod \\
\hline P1 & $0-1 ; 1 ; 0-1,1,1$ & $0 ; 0 ; 0,2,2-3$ \\
P2 & $1 ; 1-3,2,0-1$ & $0 ; 1 ; 1,2,3$ \\
P3 & $1 ; 0-2,2,1$ & $0 ; 1 ; 2,2,3$ \\
P4 & $1 ; 1-2,2,0-1$ & $0 ; 1 ; 2,2,3$ \\
\hline
\end{tabular}

exopodal segment. P2-P4 exopod 3-segmented, endopod 2segmented. Armature formula P1-P4 in Table 5.

Female P5 endopodal lobe with 4-5 setae; exopod with five setae. Male P2, P4 as in female. Male P3 endopod modified, outer spine modified in apophysis located on anterior surface of Enp2. Male P5 endopodal lobe with twothree setae, exopod with 3-5 setae.

ECOLOGY AND DISTRIBUTION. Heteropsyllus is an exclusively marine genus; it does not occur in desalinated waters. Apparently, the species of the genus, typical inhabitants of silts, can occur at different depths. Geographically, the genus has a limited range. To date, the southernmost finds are limited to the Sedlo and Seine seamounts near the Canary Islands [Büntzow, 2011]; a number of species are known for the Mediterranean [Soyer, 1974]. In the Atlantic, it is limited to the eastern part and has not been encountered off the coast of America. Also, the genus is quite common in the seas of the Arctic Ocean, from where 4 species are described together with a new species [Smirnov, 1946; Kornev, Chertoprud, 2008; Novikov, Sharafutdinova, 2021]. In the Pacific Ocean, the distribution is unknown due to low knowledge, one species is known near Jeju Island (South Korea) [Nam, Lee, 2006]. Most likely, the distribution of the genus is limited to the shores of the Palaearctic.

KEY TO THE SPECIES OF THE GENUS HETEROPSYLLUS (MODIFIED FROM NoviKov, SharafutdinOva [2021])

1. P1 Exp3 with 5 setae .................................................... 2

- P1 Exp3 with 4 setae .................................................. 7

2. P2 Enp2 with 6 setae. White Sea, Laptev Sea .................. ..H. coulli Kornev et Chertoprud, 2008

- P2 Enp2 with 5 setae ................................................... 3

- P2 Enp2 with 4 setae .................................................... 5

3. P4 Enp2 with 5 setae, anal operculum with spinules. Kara Sea, Laptev Sea*

......H. spongiophilus Novikov et Sharafutdinova, 2021

- P4 Enp2 with 4 setae, anal operculum naked ................. 4

4. P1 Enp3 twice as long as Enp2; syncoxa of maxilliped with 2 setae. North Sea, Mediterranean Sea, Laptev Sea H. exiguus (G.O. Sars, 1911)

- P1 Enp3 equal in length to Enp2; syncoxa of maxilliped with 1 seta. Mediterranean Sea

$H$ meridionalis Soyer, 1974

5. P3 Enp2 with 5 setae .................................................. 6

- P3 Enp2 with 4 setae. North Sea H. masculus Kunz, 1971

6. Endopodal lobe of baseoendopod P5 with 5 setae. Arctic Ocean .................. H. rostratus similis Smirnov, 1946

- Endopodal lobe of baseoendopod P5 with 4 setae. North Sea, Kara Sea, Laptev Sea H. rostratus s.str (G.O. Sars, 1920)

7. Endopodal lobe of baseoendopod P5 with 5 setae ........ 8 
- Endopodal lobe of baseoendopod P5 with 4 setae. IcelandFaroe ridge .... .. H. serratus Schriever, 1983

8. P5 with fused baseoendopod and exopod. Mediterranean Sea ..H. confluens Soyer, 1974

- P5 with separated baseoendopod and exopod 9 (H. curticaudatus species group)

9. P5 baseoendopod without circular wrinkled area ........ 10

- P5 baseoendopod with circular wrinkled area ................ 12

10. Syncoxa of maxilla with proximal endite. Laptev Sea* H. spiridonovi sp.n.

- Syncoxa of maxilla without proximal endite .................. 11

11. Mandible with exopod with one seta. North Sea, Mediterranean Sea......

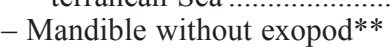

H. major (G.O. Sars, 1920) sensu Lang, 1948

P4 Enp2 with 1 inner seta. North Sea, Celtic Sea H. curticaudatus T. Scott, 1894

- P4 Enp2 with 2 inner setae 13

13. Surface of somite normal, male P5 exopod with inner

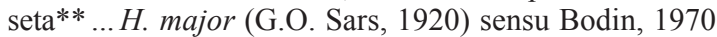

- Surface of somite areolated, male P5 exopod without inner seta

14

14. A2 exopod 2-segmented. Celtic Sea ..........................

- A2 exopod 1-segmented. Yellow Sea H. coreanus Nam et Lee, 2006

Supplementary Table is available online.

Supplement. States for characters listed in Table 1.

Acknowledgements. We would like to thank Ekaterina Abramova (Lena Delta Nature Reserve) and Waldemar Schneider for their assistance in collecting samples.

Compliance with ethical standards

CONFLICTS OF INTEREST: The authors declare that they have no conflicts of interest.

\section{References}

Bodin P. 1970. Copépodes Harpacticoides marins des environs de La Rochelle. 1. Espèces de la vase intertidale de Châtelaillon // Tethys. Vol.2. No.2. P.385-436.

Büntzow M. 2011. Vergleichende gemeinschaftsanalytische und taxonomische Untersuchungen der Harpacticoidenfauna der Seeberge „Sedlo“ und „Seine“ (nördlicher Mittelatlantik). Doctoral dissertation. Universität Oldenburg. $226 \mathrm{~S}$.

Chertoprud E., Abramova E., Korsun S., Martynov F., Garlitska L. 2018. Composition of Harpacticoida (Crustacea, Copepoda) of the Laptev Sea in comparison with faunas of adjacent Arctic seas // Polar Biology. Vol.41. No.4. P.697-712. https://doi.org/ 10.1007/s00300-017-2229-6

Coull B.C., Grant J. 1981. Encystment discovered in a marine copepod // Science. Vol.212. No.4492. P.42-344. https:// doi.org/10.1126/science. 212.4492 .342

Coull B.C. 1975. Three New Harpacticoid Copepods From the North Inlet Estuary, Georgetown, South Carolina, USA // Crustaceana. Vol.29. No.2. P.113-126. https://doi.org/10.1163/ $156854075 \times 00135$

Coull B.C., Palmer M.A. 1980 Heteropsyllus (Copepoda, Harpacticoida): a revised key, including a new species from Chesapeake Bay // Transactions of the American Microscopical Society. Vol.99. No.3. P.303-309. https://doi.org/10.2307/ 3226005

** distribution is not indicated, since probably $H$. major is of several different species.
Garlitska L.A., Chertoprud E.S., Portnova D.A., Azovsky A.I. 2019. Benthic Harpacticoida of the Cara sea: species composition and bathymetric distribution // Oceanology. Vol.59. No.4. P.600-611. https://doi.org/10.31857/s0030-1574594600-611

George K.H. 2013. Faunistic research on metazoan meiofauna from seamounts-a review // Meiofauna marina. Vol.20. P.132 .

Hamond R. 1971. The Australian species of Mesochra (Crustacea: Harpacticoida), with a comprehensive key to the genus // Australian Journal of Zoology Supplementary Series. Vol.19. No.7. P.1-32. https://doi.org/10.1071/ajzs007

Horvath T.G., Whitman R.L., Last L.L. 2001. Establishment of two invasive crustaceans (Copepoda: Harpacticoida) in the nearshore sands of Lake Michigan // Canadian Journal of Fisheries and Aquatic Sciences. Vol.58. P.1261-1264. https://doi.org/ 10.1139/cjfas-58-7-1261

Huys R., Boxshall G.A. 1991. Copepod Evolution. London: The Ray Society Publ. 468 p.

Kornev P.N., Chertoprud E.S. 2008. [Copepod crustaceans of the order Harpacticoida of the White Sea: morphology, systematics, ecology]. Moscow: KMK Scienific Press. 379 p. [In Russian]

Kunz H. 1974. Harpacticoiden (Crustacea, Copepoda) aus dem Küstengrundwasser der französischen Mittelmeerküste // Zoologica Scripta. Vol.3. No.5-6. P.257-282. https://doi.org/ 10.1111/j.1463-6409.1974.tb00822.x

Lang K. 1948. Monographie der Harpacticiden I + II. Lund: Nordiska Bokhandeln. $1683 \mathrm{p}$

Mielke W. 1984. Some remarks on the mandible of the Harpacticoida (Copepoda) // Crustaceana, Vol.46. No.3. P.257-260. https://doi.org/10.1163/156854084x00162

Moura G., Pottek M. 1998. Selenopsyllus, a new genus of Cylindropsyllinae (Copepoda, Harpacticoida) from Atlantic and Antarctic deep waters // Senckenbergiana maritima. Vol.28. No.4 6. P.185-209. https://doi.org/10.1007/bf03043149

Nam E.J., Lee W. 2006. Two new species of the genus Heteropsyllus (Crustacea, Copepoda, Harpacticoida) from Jeju Island, Korea and Devon, England // Journal of Natural History. Vol. 40. No.29-31. P.1719-1745. https://doi.org/10.1080/ 00222930600909428

Novikov A., Sharafutdinova D. 2021. Two new Canthocamptidae (Copepoda, Harpacticoida) from sponges of the Kara and Laptev Seas // Zootaxa. Vol.4948. No.3. P.336-362. https://doi.org/ 10.11646/zootaxa.4948.3.2

Por F.D. 1986. A re-evaluation of the family Cletodidae Sars, Lang (Copepoda, Harpacticoida) // Syllogeus. Vol.58. P.420-425.

Sars G.O. 1920. Copepoda Supplement. Parts V \& VI. Harpacticoida (continued). An Account of the Crustacea of Norway, with short descriptions and figures of all the species. Bergen Museum, Bergen. Vol.7. P.53-72.

Schriever G. 1983. New Harpacticoidea (Crustacea, Copepoda) from the North-Atlantic Ocean. III. New species of the family Cletodidae // Meteor Forschungserg. Vol.36. P.65-83. https:// doi.org/10.1111/j.1463-6409.1984.tb00043.x

Scott T. 1894. Additions to the fauna of the Firth of Forth. Part VI// Report of the Fishery Board for Scotland. Vol.12. No.3. P.231271

Smirnov S.S. 1946. [New species of Copepoda-Harpacticoida from the northern Arctic Ocean] // Trudy Dreifuyushchei ekspeditsii Glavsevmorputi na ledokol'nom parokhode 'G. Sedov', 19371940. Vol.3. P.231-263 [in Russian].

Soyer J. 1975. Contribution a l'étude des Copépodes Harpacticoïdes de Méditerranée occidentale. 12. Le genre Heteropsyllus (T. Scott) Cletodidae T. Scott // Vie et Milieu. Sér.A. Vol.24. No.3. P.505-518.

Ustach J.F. 1982. Algae, bacteria and detritus as food for the harpacticoid copepod, Heteropsyllus pseudonunni Coull and Palmer // Journal of Experimental Marine Biology and Ecology. Vol.64. No.3. P.203-214. https://doi.org/10.1016/00220981(82)90010-7 